\title{
Analysing Arguments in Networked Conversations: The Context of Student Teachers
}

\section{MILTON N. CAMPOS}

Université de Montréal

THÉRÈSE LAFERRIÈRE

Université Laval

JUDITH M. LAPOINTE

University of Houston

\section{ABSTRACT}

The purpose of this article is to demonstrate how the method of meaning implication discourse analysis can be applied in the context of online collaborative reflective practice of student teachers. The method was developed to identify knowledge building in networked contexts. It derives from the model of meaning implication developed by Piaget, and the model of "schematization" proposed by Grize. It also borrows from the knowledge building theory developed by Scardamalia and Bereiter. The method allows understanding knowledge construction as an evolving process of conceptual change and learning through argumentation. We present two studies in which online "conversations" of pre-service teachers are analyzed. Contributions for higher education are discussed. 


\section{RÉSUMÉ}

L'objectif de cet article est de démontrer comment la méthode d'analyse du discours fondée sur l'implication signifiante permet d'analyser la pratique réflexive d'étudiants en enseignement dans un contexte de collaboration en réseau. Cette méthode a été développée dans le but de repérer la coélaboration de connaissances dans ce contexte. Elle provient du modèle de l'implication signifiante développé par Piaget ainsi que du modèle de la schématisation proposé par Grize, et s'inspire aussi de la théorie de la coélaboration des connaissances de Scardamalia et Bereiter. La méthode permet de comprendre la construction des connaissances comme étant un processus de changement conceptuel et d'apprentissage rendu possible par l'argumentation. Nous présentons deux études dans lesquelles les « conversations » en réseau d'étudiants en enseignement sont analysées. La contribution que cette méthode peut apporter au domaine de l'éducation universitaire est par la suite discutée.

\section{INTRODUCTION}

In this paper, we analyze online conference transcripts to seek evidence of collaborative learning and knowledge building (Campos, 2004a) in the professional development context of student teachers collaborating to discuss their instructional practices. The potential value of integrating electronic conferencing in learning communities (online or mixed-mode) has been widely recognized. However, there is still limited evidence of relevant, adequate and skilful use by teachers and students. Methodological procedures that verify the presence of learning resulting from collaboration in electronic conferencing are scarce. Older literature showing the capacity to promote idea linking and structuring in online contexts indirectly chronicles the development of methods of transcript analysis (Bruer, 1994; Harasim, 1990; Harasim, Hiltz, Teles, \& Turoff, 1995; Scardamalia, \& Bereiter, 1994). More recent learning studies demonstrate that deep understanding through argumentation (Campos, 1998; 2000), creativity and innovation (Scardamalia, 2002) lead to online knowledge building. Based upon online collaborative reading and writing processes, these 
studies presented qualitative circumscribed evidence of progressive online discourse serving as theoretical support for the development of our method of meaning implication discourse analysis.

Our goal is to show that this method can also be useful in the context of "conversations" of student teachers. The meaning implication discourse analysis was already applied in networked argumentation contexts of higher education (Campos, 2000; Laferrière, Murphy \& Campos, 2005), workplaces (Campos, 2004a; Laferrière, Campos \& Benoit, 2004) and healthcare (2004b; 2004c). We collected and analyzed data from networked communities of pre-service teachers. The outcomes confirmed results recently published and provided additional evidence of its applicability.

\section{THEORETICAL FRAMEWORK}

The method of discourse analysis presented here is at the cross-road of different disciplines: epistemology, psychology, logic and communication. From a constructivist epistemological viewpoint, it relies on the model of “meaning implication"1 developed by Jean Piaget at the end of his life(1991). This model was intended to update his model of knowledge construction based on progressive logical inclusions that explain development (Piaget, 1950; 1976a). Moreover, the model of meaning implication explained how logical inclusions were related to meanings and highlighted its fundamental importance in the inferencing process.

This theoretical innovation (that few researchers have explored) allows researchers interested in networked discourse analysis to understand knowledge construction as an evolving process of conceptual change leading to learning (adaptation that follows assimilation and accommodation) that could only be identified in the context of meaning-making. Meaning implication discourse analysis is consistent with most socio-constructivist claims such as those of the fundamental importance of language in defining human behaviour. It is also consistent with the zone of proximal development in learning processes (Vygotsky, 1979)2 . The application of this integrated framework to the online environment is given by the notion of "progressive discourse." This notion, based on reading and writing processes enabled by appropriate software (Scardamalia \& Bereiter, 1994; 2002), allows the researchers to study learning in collaboration through 
the networked exchange of ideas (Scardamalia, 2002). Any exchange of ideas is seen here as an ill defined problem solving process (Bruer, 1994).

The meaning implication discourse analysis, based on the integration of the model of operatory logic (first Piaget) and the model of meaning implication (second Piaget) leads to the notion of "idea confrontation" found in argumentation processes. Idea confrontation has been a matter of logic. More specifically, logic developed by those concerned with the limitations of formalism, known as "informal logicians." They were willing to go beyond the realm of form as did Piaget's collaborator Jean-Blaise Grize. Grize is internationally recognized as one of the most important theoreticians of contemporary argumentation theory (Van Eemeren, Grootendorst, \& Henkemans, 1996). He developed a constructivist model of communication based on the idea of knowledge construction and coconstruction (1991). His model, called "schematization" explores how ideas are constructed and co-constructed in argumentation processes. The "schematization" model, inspired by the second Piagetian theory, enabled us to develop our method of meaning implication discourse analysis to study communicational exchanges in networked contexts as argumentation processes (Breton, 1996; De Kerckhoeve, 1997). It allows us to look at the inferencing processes of the mind that could be traced through discourse. Inferencing is at the core of reflective thinking that may lead the individual to conceptual change, and thus to learning. Inferencing processes of this kind are seen as ill-defined problem solving processes that are subjacent to knowledge construction and co-construction, and to knowledge building ${ }^{3}$.

\section{Networked argumentation: intermediate consideration}

Research points to the need for better understanding of asynchronous networked communication (Campos, 1998; 2000; Campos \& Laferrière, 2002; Campos, Laferrière, \& Harasim, 2001) in community contexts in order to enhance problem-solving skills and learning through processes of reflective thinking, inquiry, and interpretation (Breuleux, 2001; Breuleux \& Laferrière, 2000; Campos, 2003; 2004a; Lamon, Scardamalia, \& Laferrière, in press). It also points to the need for evaluating "what effective learning strategies and modes of learning make the most use of 
the capabilities of the new technologies” (Haughey, 2002, p. 18).

Cognitive science and psychology rely heavily on the first Piaget model. This model is the operatory logic which, according to Piaget, expresses brain functioning (1976a). It is closely related to the information processing tradition in cognitive science and psychology. Logical operations subjacent to physical or symbolic actions are, for Piagetian theory, what procedures are for information processing theory. Both theories have studied problemsolving processes extensively, mostly in well-defined domains such as mathematics and physics. Normally, the procedures to solve these kinds of problems follow a number of clear mental routes (or strategies), that are progressively constructed. They enable, for example, artificial intelligence (AI) researchers to model them in software interfaces. However, knowledge about ill-defined problem-solving based on language is far less developed. Most publications on the subject have ignored the contributions provided by the second Piaget model. In the 1970s, Piaget tried to clarify misunderstandings around the place of meanings in his theory in a number of articles (1976b, 1977). Although he had always written that all actions (physical as well as symbolic) have logical systems subjacent to meaning systems (Piaget, 1950), the fact that meanings were implicit in the model of operatory logic (1976a) was problematic. To make them explicit in the explanation of human symbolic behaviour, he developed the notion of meaning implication (1991) to enhance his first model. This notion allowed the logical inclusions observed by Piaget in human development that led to the model of operatory logic to be explained explicitly also in terms of meanings. Enhancing operatory logic, the notion of meaning implication allowed Piagetian theory to deal with ill-defined problems emerging in symbolic interaction mediated by language, such as in argumentation.

Argumentation is not understood here as "arguing," which carries a somewhat negative meaning. As Grize explains (1991), argumentation is usually understood as a process in which an individual provides reasons to defend a thesis through reasoning, justification and synthesis (hard core argumentation). However, it could also be understood as conversation, threading opinions (soft core argumentation). We understand argument as a natural conditional structure (If-Then) engendering premises that lead or do not lead to conclusions (Grize, 1991). In interactive contexts, 
arguments need to be co-constructed (Grize, 1991). In the interactive context of electronic conferencing, they need to be built ${ }^{4}$. In this case, the argumentation process requires that people respond and actively engage in responding to the messages that are posted in an electronic conferencing system, forming the "online discourse."

Although research in electronic conferencing (writing and reading) is limited, existing research, consistent with other developments in the field (Bereiter \& Scardamalia, 1987; 1996; Bruer, 1994; Hewitt, 2001; Scardamalia, 2002), suggests that "online conversation" or "networked argumentation" can scaffold ill-defined problem-solving in electronic conferencing. (i.e., enable argumentation processes). Network-enabled argumentation is thus understood as a collaborative process of engagement in which two or more people, through the use of a given communication software, express and build on the thoughts and ideas of one another through cognitions and emotions (Piaget, 1954). Knowledge building represents a collective process of production and improvement of ideas that are valuable for a networked community in which the sum of individual contributions is less fundamental than what the community as a whole could accomplish by engaging in knowledge production, creation, improvement and innovation (Scardamalia, 2002). The method that will be described was tailored to identify knowledge building.

\section{METHOD AND ANALYSIS}

This three step discourse analysis method consists of capturing inferencing trends in online discourse able to demonstrate (1) that a discursive reflective practice is under way, (2) that through written traces of logical terms the inferencing process of symbolic assimilation and accommodation leading to conceptual change (which is the strongest indicator of learning) can be identified, and (3) that this process is a collaborative one and that no individual authorship could be claimed.

\section{First step}

For the first step, the method adopts the sentence as the coding unit. This step consists of identifying basic logical operations underlying discourse 
in order to reveal the nature of the inquiry (Campos, 1998; 2000; 2002) as illustrated in Table 1.

Table 1

First Step: Logical Operations

\begin{tabular}{ll}
\hline \multicolumn{1}{c}{ Logical operation } & \multicolumn{1}{c}{ Meaning } \\
\hline Affirmation & Sentences have positive meanings \\
Negation & Sentences have negative meanings \\
Conditional & $\begin{array}{l}\text { Sentences have, explicitly, or implicitly, the form "if-then" } \\
\text { Disjunction }\end{array}$ \\
& $\begin{array}{l}\text { Sentences have the form “either-or" or "neither-nor", } \\
\text { inclusive or exclusive }\end{array}$ \\
\hline
\end{tabular}

\section{Second step}

The coding unit of the second step is the message. This step consists of identifying the main functions of arguments by looking at the content of the messages that manifest how inferences are structured (Campos, 2004a) $)^{5}$. The main functions are displayed in Table 2.

Table 2

Step 2 - Main Functions of Arguments

\begin{tabular}{|c|c|c|}
\hline $\begin{array}{r}\text { Functions of } \\
\text { arguments }\end{array}$ & Meanings & Occurrence \\
\hline Claiming & Stating something & $\begin{array}{l}\text { Claims can be: } \\
\text { - Affirmations ("This is true”) } \\
\text { - Negations ("This is not true”) } \\
\text { - Disjunctions ("Either-or", "neither- } \\
\text { nor") }\end{array}$ \\
\hline $\begin{array}{l}\text { Presenting } \\
\text { data }\end{array}$ & $\begin{array}{l}\text { Provinding evidence such as } \\
\text { facts, statistics, scientific } \\
\text { data and research results, } \\
\text { or subjective opinions such } \\
\text { as perceptions, beliefs, } \\
\text { values, expectations, etc. }\end{array}$ & $\begin{array}{l}\text { Data can be: } \\
\text { - Affirmations (“I present } \\
\text { data according to which 'x' } \\
\text { demonstrates 'y'”) } \\
\text { - Negations ("I present data } \\
\text { according to which 'x' does not } \\
\text { demonstrate 'y””) } \\
\text { - Disjunctions ("Either/neither this } \\
\text { datum or/nor that one”) }\end{array}$ \\
\hline Hypothesizing & $\begin{array}{l}\text { Engaging in a process of } \\
\text { hypotheses formulation }\end{array}$ & $\begin{array}{l}\text { Hypotheses can be: } \\
\text { - Implicit (“I have 'y' because of } \\
\text { 'x'”) or } \\
\text { - Explicit (“If 'x' then 'y’”) }\end{array}$ \\
\hline
\end{tabular}




\section{Third step}

The coding unit of the third step is the thread. This step consists of identifying the main ideas being discussed or themes (Grize \& Pierault-Le Boniec, 1991) ${ }^{6}$. It also seeks to establish links among inferences across messages (meaning implication) in order to verify how meanings "imply” (or mould) other meanings (Piaget, 1991).

\section{The Studies}

The studies were done with transcript data coming from learning communities of pre-service teachers registered at a francophone Canadian university. Traditionally, as in most institutions of higher education, student teachers are assigned with professional journals that must be handed to their university supervisors. However, since 1996, this process was changed in the studied institution with the introduction of electronic conferencing?. Instead of individual reports, they were requested to share, and reflect upon their experiences with each other in an online community. The assumption was that pre-service teachers would benefit from reflecting collaboratively upon their different teaching experiences, hence enriching the practices of everyone. In addition, the created collective knowledge would be made available to future incoming students thanks to digital databases.

In the studies presented below, the following must be mentioned:

a. instructors were different in terms of status, background, and content chosen to be taught;

b. data were generated either by the Virtual-U or Knowledge Forum conferencing systems;

c. participating subjects in the first study were pre-service teachers registered in the $3^{\text {rd }}$ year while those of the second study were registered in the $4^{\text {th }}$ year of their B.Ed.;

d. inter-coder reliability was achieved by double blind coding (the coders were thoroughly trained before working on the transcripts).

No attempt was made to compare aspects of each study (e.g., software, students or instructors). The focus remained on the usefulness of the method in demonstrating how collaborative learning leading to knowledge 
building had occurred (or not occurred) through the inferencing process of meaning implication. To propitiate a minimum of homogeneity across data, we chose excerpts that focus on the same discussion content: student motivation and engagement.

\section{Study 1}

Software.

Virtual-U is an online learning environment that has a built-in conferencing system (VGroups).

\section{Data.}

Two conference threads that follow chronologically one another were studied. The first thread has four messages while the second, seven messages.

\section{Results.}

\section{$\underline{\text { Step } 1}$}

In the first forum thread, logical operations are distributed as follows (see Table 3).

Table 3

Step 1 of the First Thread (Study 1): Logical Operations

\begin{tabular}{lr}
\hline \multicolumn{1}{c}{ Logical operation } & $\%$ \\
\hline (Including ambiguity) & 44.0 \\
Affirmations & 4.5 \\
Negations & 33.0 \\
Conditionals & 4.5 \\
Disjunctions & 14.0 \\
Ambiguous phrases & \\
\hline (Excluding ambiguity) & 51.0 \\
Affirmations & 5.0 \\
Negations & 39.0 \\
Conditionals & 5.0 \\
Disjunctions & \\
\end{tabular}


In the second thread, logical operations are distributed as follows as portrayed in Table 4.

Table 4

Step 2 of the Second Thread (Study 1): Logical Operations

\begin{tabular}{lc}
\hline \multicolumn{1}{c}{ Logical operation } & $\%$ \\
\hline (Including ambiguity) & \\
Affirmations & 43 \\
Negations & 15 \\
Conditionals & 28 \\
Disjunctions & 2 \\
Ambiguous phrases & 12 \\
\hline (Excluding ambiguity) & \\
Affirmations & 40 \\
Negations & 17 \\
Conditionals & 32 \\
Disjunctions & 2 \\
\hline
\end{tabular}

Ambiguous phrases are those having more than one logical operation. The inter-coder reliability for both threads was $93 \%$.

\section{Step 2}

In the first thread, the main functions of arguments are distributed as displayed in Table 5.

Table 5

Step 2 of the First Thread (Study 1): Functions of Arguments

\begin{tabular}{ll}
\hline \multicolumn{1}{c}{ Functions of arguments } & $\%$ \\
\hline (Including unrelated phrases) & 12 \\
Claiming & 35 \\
Persenting data & 35 \\
Hypothesizing & 18 \\
Unrelated phrases & \\
\hline (Excluding related phrases) & 14 \\
Claiming & 43 \\
Presenting data & 43 \\
Hypothesizing & \\
\hline
\end{tabular}

The Canadian Journal of Higher Education

Volume XXXV, No. 4, 2005 
In the second thread, the main functions of arguments are distributed as follows (see Table 6).

Table 6

Step 2 of the Second Thread (Study 1): Functions of Arguments

\begin{tabular}{ll}
\hline \multicolumn{1}{c}{ Functions of arguments } & $\%$ \\
\hline (Including unrelated phrases) & \\
Claiming & 19 \\
Persenting data & 41 \\
Hypothesizing & 25 \\
Unrelated phrases & 15 \\
\hline (Excluding related phrases) & \\
Claiming & 22 \\
Presenting data & 49 \\
Hypothesizing & 29 \\
\hline
\end{tabular}

Unrelated phrases were those that did not pertain to arguments such as "Hi there", and so forth. Quantitative data presented above reveal that in the thread of the first forum, most phrases were affirmations, the number of conditionals was impressive, and that of negations and disjunctions less important but not meaningless. By looking at the functions of arguments, it is possible to note that in the first thread the sum of the percentages of claims and data is close to that of affirmations, negations and disjunctions taken altogether. The percentage of conditionals is in line with that of hypothesizing (see Table 7).

In the second thread, the percentage of conditionals is consistent with that of hypothesizing while that of affirmations and negations taken altogether are in line with the sum of claims and data (see Table 8).

The numbers suggest that, in the first thread, hypothesis formulation relies mainly on affirming things through claims and presenting data to support them while in the second thread a cognitive conflict is apparent due to negation. However, the presence of a cognitive conflict does not result in a higher level of hypothesizing, as we should expect. Previous 
research has shown that negations scaffold thought reorganization leading to further hypothesis formulation (Campos 2000, 2004a). This process was not observed in this thread..

Table 7

Crossing Logical Operations and Functions of Arguments of the First Thread (Study 1)

\begin{tabular}{lc}
\multicolumn{1}{c}{ Logical operations } & $\%$ \\
\hline (Excluding ambiguity) & 51 \\
Affirmations & 5 \\
Negations & 29 \\
Conditionals & 5 \\
Disjunctions & \\
\hline (Excluding related phrases) & 14 \\
Claiming & 43 \\
Presenting data & 43 \\
Hypothesizing & \\
\hline
\end{tabular}

Table 8

Crossing Logical Operations and Functions of Arguments of the Second Thread (Study 1)

\begin{tabular}{ll}
\hline \multicolumn{1}{c}{ Logical Operations } & $\%$ \\
\hline (Excluding ambiguity) & 49 \\
Affirmations & 17 \\
Negations & 32 \\
Conditionals & 2 \\
Disjunctions & \\
\hline (Excluding related phrases) & 22 \\
Claiming & 49 \\
Presenting data & 29 \\
Hypothesizing & \\
\hline
\end{tabular}

\section{$\underline{\text { Step } 3}$}

The main recurrent theme in the pre-service teachers' discourse that we retained was that of motivation: they shared experiences in which they tried, without success, to motivate students. By looking at the implication 
among meanings related to this theme (inferencing mainly revealed by conditionals and hypothesizing procedures), no apparent conceptual change could be found. Here, participants just suggested alternatives without reflecting upon the reasons that lead students not to pay attention to content developed in the classroom.

In the first thread, a pre-service teacher presented the problem of a student drawing pictures while he/she was expected to do class work and pay attention, reporting that he/she was warned ${ }^{8}$ (Table 9).

Table 9

Inferences of the First Thread (Study 1)

\begin{tabular}{lc}
\hline Inferences captured from online conversation content & Code \\
\hline $\begin{array}{l}\text { The first pre-service teacher requested the help of colleagues: “IF my } \\
\text { strategy did not work THEN do I do the same or what?” }\end{array}$ & A \\
The second suggests that "IF the strategy did not work THEN EITHER \\
he/she does the same OR seizes the drawing” \\
$\begin{array}{l}\text { The third pre-service teacher says that "IF the strategy did not work, } \\
\text { THEN he/she would seize the drawing” }\end{array}$ \\
$\begin{array}{l}\text { The fourth suggests that "IF my strategy did not work THEN he/she } \\
\text { would let the student do whatever he/she wanted to" }\end{array}$ \\
\hline
\end{tabular}

In Table 10, if the meaning implication transitivity is applied:

Table 10

Meaning Implications of the First Thread (Study 1)

\begin{tabular}{l}
\hline \multicolumn{1}{c}{ Premises } \\
\hline IF part of the meaning $m$ of $\mathrm{C}$ is embedded in $\mathrm{D}$ \\
IF part of the meaning $m$ of $\mathrm{B}$ is embedded in $\mathrm{C}$ \\
IF part of the meaning $m$ of A is embedded in B \\
\hline Conclusion \\
IF part of the meaning $m$ of A is embedded in D \\
\hline
\end{tabular}

No conceptual change can be captured from this sequence of discourse events because no higher hypothesizing can be identified. Meanings shared just suggest a low-level of collaborative efforts and no knowledge building 
can be seen. Although suggestions of solutions to the problem were presented, all that can be said is that the pre-service teachers engaged in a low level ill-defined problem solving process that remained informative in nature, and did not produce an in-depth reflection about the problems lying behind the lack of student motivation and engagement observed during traditional teaching.

In the second thread, a pre-service teacher who teaches history tells that he/she used music at the end of the day to create a Middle Age ambiance, asking the students to close their eyes and imagine castles, princesses, and kings. However, the students were not interested and he/she decided to ask them questions without good results either (see Table 11).

Table 11

Inferences of the Second Thread (Study 1)

\begin{tabular}{|c|c|}
\hline Inferences captured from online conversation content & Code \\
\hline $\begin{array}{l}\text { A pre-service teacher asks colleagues: "IF this is so interesting, THEN } \\
\text { why don't the students find the same?" }\end{array}$ & $\mathrm{E}$ \\
\hline $\begin{array}{l}\text { The supervisor of the practicum commented that "IF he/she wanted } \\
\text { to make the students reflect, THEN how could he/she be sure that } \\
\text { it would work at the end of the day? IF he/she is not sure, THEN } \\
\text { another strategy should be used" }\end{array}$ & $\mathrm{F}$ \\
\hline $\begin{array}{l}\text { The following student teacher says that "IF not strategy works, THEN } \\
\text { he/she could distribute cards with questions to give the students time } \\
\text { to reflect upon the answers" }\end{array}$ & G \\
\hline $\begin{array}{l}\text { This comment is followed by another one in which the pre-service } \\
\text { teacher says that "IF he/she distributes cards with questions, THEN } \\
\text { he/she should not be discouraged" }\end{array}$ & $\mathrm{H}$ \\
\hline $\begin{array}{l}\text { The next student suggests that "IF the strategy does not work, THEN } \\
\text { he/she should meet the school pedagogical counsellor" }\end{array}$ & I \\
\hline $\begin{array}{l}\text { The following student advises that "IF questioning does not work that } \\
\text { way, THEN questions could be given to a group of students instead of } \\
\text { one to avoid them feeling embarassed" }\end{array}$ & $\mathrm{J}$ \\
\hline $\begin{array}{l}\text { The thread ends with a pre-service teacher saying that "nothing could be } \\
\text { done" }\end{array}$ & $\mathrm{K}$ \\
\hline
\end{tabular}

If the meaning implication transitivity is applied, it is possible to verify, another time, that no conceptual change took place and, again, no knowledge building occurred. The second thread adds nothing to the first. 


\section{Study 2}

Software used.

Knowledge Forum is a conferencing system developed by researchers to support knowledge building (Scardamalia \& Bereiter, 2002). It has web and client versions. The learning community of the pre-service teachers used the client version. In addition to features found in most conferencing systems (e.g., key-wording, word search), Knowledge Forum allows users to insert scaffolds that enable discourse structuring ${ }^{9}$.

Data.

Two conference threads that follow one another in time were studied. The first thread has five messages while the second, seven messages.

Results.

$\underline{\text { Step } 1}$

In the first forum thread, logical operations are distributed as portrayed in Table 12.

Table 12

Step 1 of the First Thread (Study 2): Logical Operations

\begin{tabular}{lr}
\hline \multicolumn{1}{c}{ Logical operation } & $\%$ \\
\hline (Including ambiguity) & \\
Affirmations & 57.0 \\
Negations & 6.0 \\
Conditionals & 21.0 \\
Disjunctions & 6.0 \\
Ambiguous phrases & 10.0 \\
\hline (Excluding ambiguity) & \\
Affirmations & 64.0 \\
Negations & 6.5 \\
Conditionals & 23.0 \\
Disjunctions & 6.5 \\
\hline
\end{tabular}


In the second forum thread, logical operations are distributed as follows (Table13).

Table 13

Step 2 of the Second Thread (Study 2): Logical Operations

Logical operation \%

(Including ambiguity)

Affirmations $\quad 60$

Negations $\quad$ Nul

Conditionals $\quad 24$

Disjunctions Nul

Ambiguous phrases 16

(Excluding ambiguity)

Affirmations $\quad 71$

Negations $\quad$ Nul

Conditionals $\quad 29$

Disjunctions Nul

The inter-coder reliability for both threads was $82 \%$.

Step 2

In the first forum thread, the main functions of arguments are distributed as indicated in Table 14.

Table 14

Step 2 of the First Thread (Study 2): Functions of Arguments

\begin{tabular}{lc}
\hline \multicolumn{1}{c}{ Functions of arguments } & $\%$ \\
\hline (Including unrelated phrases) & 21 \\
Claiming & 40 \\
Persenting data & 39 \\
Hypothesizing & $\mathrm{Nul}$ \\
Unrelated phrases & \\
\hline (Excluding related phrases) & 21 \\
Claiming & 40 \\
Presenting data & 39 \\
Hypothesizing &
\end{tabular}

The Canadian Journal of Higher Education

Volume XXXV, No. 4, 2005 
In the second forum thread, the main functions of arguments are distributed as follows in Table 15.

Table 15

Step 2 of the Second Thread (Study 2): Functions of Arguments

\begin{tabular}{lc}
\hline \multicolumn{1}{c}{ Functions of arguments } & $\%$ \\
\hline (Including unrelated phrases) & 24 \\
Claiming & 47 \\
Persenting data & 25 \\
Hypothesizing & 4 \\
Unrelated phrases & \\
(Excluding related phrases) & 24 \\
Claiming & 50 \\
Presenting data & 26 \\
Hypothesizing & \\
\hline
\end{tabular}

The inter-coder reliability for both threads was $82 \%$.

Quantitative data presented reveal that in the first thread a significant majority of the phrases were made of affirmations, the number of conditionals was reasonable and that of negations and disjunctions less important but not meaningless. The percentage of claims and data in the arguments found is consistent with that of affirmations though it is striking to remark that the percentage of conditionals is much smaller than that of hypothesizing. However, in this case, negations and disjunctions were used in hypothesis formulation (see Table 16).

In the second thread, an impressive majority of affirmations and a reasonable number of conditionals was also found. The argumentation functions are consistent with that of the above logical trends: the sum of the percentages of claims and data are in line with that of affirmations and the percentage of conditionals is consistent with that of hypothesizing (see Table 17).

These numbers suggest that, in the first thread, hypothesis formulation is particularly strong while in the second thread it is less prevalent. 
Table 16

Crossing Logical Operations and Functions of Arguments of the First Thread (Study 2)

\begin{tabular}{lr}
\hline \multicolumn{1}{c}{ Logical operations } & $\%$ \\
\hline (Excluding ambiguity) & 64.0 \\
Affirmations & 6.5 \\
Negations & 23.0 \\
Conditionals & 6.5 \\
Disjunctions & \\
\hline (Excluding related phrases) & 21.0 \\
Claiming & 40.0 \\
Presenting data & 39.0 \\
Hypothesizing & \\
\hline
\end{tabular}

Table 17

Crossing Logical Operations and Functions of Arguments of the Second Thread (Study 2)

\begin{tabular}{lr}
\multicolumn{1}{c}{ Logical operations } & $\%$ \\
\hline (Excluding ambiguity) & 71 \\
Affirmations & Nul \\
Negations & 29 \\
Conditionals & Nul \\
Disjunctions & \\
\hline (Excluding related phrases) & 24 \\
Claiming & 50 \\
Presenting data & 26 \\
Hypothesizing & \\
\hline
\end{tabular}

\section{Step 3}

The main recurrent theme of the pre-service teachers' discourse that we chose was that of motivation and student engagement. It is related to the development of intellectual competence: student teachers establish relationships with experiences and readings in order to understand students' engagement and motivation. The implications among meanings related to this theme suggest glimpses of conceptual change (which is a strong indicator of learning). In addition, they also suggest the presence of 
knowledge building because the sequence demonstrates the improvement of plausible ideas (Scardamalia, 2002). This theme is developed along two threads and a sub-thread. The first thread is as follows (Table 18).

Table 18

Inferences of the First Thread (Study 2)

\begin{tabular}{|c|c|}
\hline Inferences captured from online conversation content & Code \\
\hline $\begin{array}{l}\text { A pre-service teacher, making use of the scaffold “I introduce a } \\
\text { problem” asks: "IF the dynamics of a learning community implies the } \\
\text { engagement of students in projects THEN how can the teacher, as a } \\
\text { guide, do that?" }\end{array}$ & A \\
\hline $\begin{array}{l}\text { The second pre-service teacher, making use of the scaffold "Putting } \\
\text { our knowledge together", provides an example in which the teacher } \\
\text { leaves the decision to identify learning goals and develop projects } \\
\text { to the students. He/She continues: "IF we give them some freedom } \\
\text { THEN they will participate better" }\end{array}$ & B \\
\hline $\begin{array}{l}\text { The third pre-service teacher, making use of the scaffold "My evaluation } \\
\text { of the situation", provides data about ways of transferring the learnig } \\
\text { responsibility to the students and enabling them to create a knowledge } \\
\text { database: "IF this database is actively created THEN the students } \\
\text { will not learn only by exercising their memory but by deepening their } \\
\text { understanding and developing their skills" }\end{array}$ & $\mathrm{C}$ \\
\hline $\begin{array}{l}\text { The fourth pre-service teacher, making use of the scaffold “I introduce a } \\
\text { problem” asks: “IF B’s proposal is right, THEN how to get there and } \\
\text { what about lecturing?” }\end{array}$ & $\mathrm{D}$ \\
\hline $\begin{array}{l}\text { The fifth pre-service teacher answers: "IF this project is made possible } \\
\text { THEN I would keep lecturing to a minimum” }\end{array}$ & E \\
\hline
\end{tabular}

Table 19 Table 19 displays the meaning implication transitivity:

Table 19

Meaning Implications of the First Thread (Study 2)

\begin{tabular}{l}
\hline \multicolumn{1}{c}{ Premises } \\
\hline IF part of the meaning $m$ of $\mathrm{D}$ is embedded in $\mathrm{E}$ \\
IF part of the meaning $m$ of $\mathrm{C}$ is embedded in $\mathrm{D}$ \\
IF part of the meaning $m$ of B is embedded in C \\
\hline Conclusion \\
IF part of the meaning $m$ of A is embedded in B, THEN A implies $\mathrm{E}$ in terms of \\
meaning
\end{tabular}


Here, a genesis of conceptual change takes place when the second preservice teacher provides a concrete example of how engagement could be achieved and hence motivate students. In addition, the third pre-service teacher works on the idea improving it by proposing a strategy. The initial question is answered because the solution is plausible although remaining hypothetical.

The second thread meaning implications are illustrated in Table 20.

Table 20

Inferences of the Second Thread (Study 2)

\begin{tabular}{|c|c|}
\hline Inferences captured from online conversation content & Code \\
\hline $\begin{array}{l}\text { One pre-service teacher, making use of the scaffold “I introduce } \\
\text { a problem” asks: “IF a learning community develops students’ } \\
\text { intellectual compentence THEN can it also develop moral values?” }\end{array}$ & $\mathrm{F}$ \\
\hline $\begin{array}{l}\text { The second pre-service teacher, making use of the scaffold “I improve } \\
\text { the idea”, adds that “IF it isn't the role of the teacher as a guide } \\
\text { to promote that THEN it's up to him/her to promote this among } \\
\text { classmates" }\end{array}$ & G \\
\hline $\begin{array}{l}\text { The third pre-service teacher, also making use of the scaffold "I improve } \\
\text { the idea", suggests that "IF guidance is cognitive, metacognitive and } \\
\text { moral THEN teachers must have an interest in the students, taking } \\
\text { into account all those dimensions and manage the class accordingly } \\
\text { and with care" }\end{array}$ & $\mathrm{H}$ \\
\hline $\begin{array}{l}\text { The fourth pre-service teacher, making use of the referencing tool to } \\
\text { reproduce the core ideas of the previous student, states that "IF what } \\
\text { has been referred to is true, THEN it's a caring approach which will } \\
\text { enable the teacher as a guide to engage students cognitively and } \\
\text { affectively" }\end{array}$ & I \\
\hline
\end{tabular}

The discussion continues in a sub-thread (Table 21).

Applying the meaning implication transitivity, it is possible to observe that it seems that conceptual change took place as a result of collaboration. In addition, knowledge building occurred because the second thread builds upon the first (see the following discussion). 
Table 21

Inferences of the Second Sub-thread (Study 2)

\begin{tabular}{|c|c|}
\hline Inferences captured from online conversation content & Code \\
\hline $\begin{array}{l}\text { The fifth pre-service teacher builds on the first pre-service teacher, making } \\
\text { use of the referencing tool to reproduce his/her question (see above). } \\
\text { Then, he/she presents research studies on ways to develop healthy } \\
\text { learning environments and, making use of the scaffold "I improve the } \\
\text { idea”, reasons as follows: "IF the guide has a role in enabling a learning } \\
\text { community in terms of knowledge and in moral terms THEN he/she } \\
\text { should build a context promoting the choice of moral values" }\end{array}$ & $\mathrm{J}$ \\
\hline $\begin{array}{l}\text { The sixth pre-service teacher, applying the scaffolds "Putting our } \\
\text { knowledge together", "I introduce a problem", "My theory" and "I } \\
\text { explore another theory”, goes on summarizing that moral education is } \\
\text { critical for the sake of a learning community, questions the role of a } \\
\text { person in judging the choices of others, discusses Hume, Mill and Kant } \\
\text { ethics and infers: "IF a community encourages interactions THEN it } \\
\text { is this richeness that enables the emergence of feeling and the need of } \\
\text { establishing rules" }\end{array}$ & K \\
\hline $\begin{array}{l}\text { The seventh pre-service teacher, making use of the scaffold "I improve the } \\
\text { idea”, concludes: "IF a learning community promotes interaction THEN } \\
\text { it promotes moral action among the students" }\end{array}$ & $\mathrm{L}$ \\
\hline
\end{tabular}

\section{Conclusion}

In Study 1, the meaning implication analysis suggests that no conceptual change took place. According to Piaget (1978), there is a net difference between succeeding when performing an action and understanding it. For example, a person can be able to ride a bike but to understand what movements are needed to do it and their relationships with gravity or balance, is something else. Concerning discourse, the analogy is applicable but in terms of meanings (Piaget, 1991), a person can succeed in identifying a problem, describing it and putting forward opinions but to understand the problem, decorticate it, reflect upon it and solve it requires logical reasoning, specifically the adequate use of valid inferences, that is, if-then operations subjacent to discourse or natural logic (Grize, 1991).

In other words, this points to the difference between cognition and metacognition. Metacognition implies an awareness of the change in the previous concepts believed to be true by the individual. Therefore, deep learning-either strictly individual or collaborative, as in the case of network- 
enabled discourse processes - seems to occur only when metacognitive procedures are in place. This did not happen in the conference threads of Study 1, and knowledge building did not happen either. The presence of an impressive number of conditionals and hypothesizing suggests that those pre-service teachers engaged in the exploration of the knowledge object but it does not tell us, however, about the depth of the inferencing process that could be observed through the implications among meanings.

Differently, Study 2 shows a situation in which conceptual change took place. Applying the meaning implication transitivity to both threads, we have the following knowledge-building process (Table 22).

In the first thread, it is possible to verify that reflections led to the conclusion that the role of the teacher is critical in promoting interaction in a learning community and that this action is understood as having a moral dimension. The second thread, including its sub-thread, confirmed the results found in the first thread. In other words, argumentation suggests that learning and knowledge building took place.

\section{FINAL THOUGHTS}

Our goal was that of applying a discourse analysis method to verify whether conceptual change (thus learning) led to knowledge building in the context of the collaborative reflective practice of student teachers. While there is no indication of conceptual change in the first study, the second one presents clear indications of conceptual change among participating student teachers. However, it is worth noting that even if the presence of conditionals and hypothesizing in the threads of the second study are less impressive than those found in the first one, only in the second product of collective thinking (or idea improvement in Scardamalia's terminology) is clearly developed.

Why is this method worth discussing in the context of student teachers? We applied it to respond to a need of providing a way to highlight the value of networked discourse. Although there is no evidence pointing to possible correlations with the software used because there were many variables that could account for them such as the stage of the students' advancement in the program (those of the first study were registered in the $3^{\text {rd }}$ year while those of the second study were registered in the $4^{\text {th }}$ year), the facilitation 
Table 22

Study 2 Knowledge-building Process, Shown by Meaning Implications

First meaning implication thread (I)

IF part of the meaning $m$ of $\mathrm{D}$ is embedded in $\mathrm{E}$

IF part of the meaning $m$ of $C$ is embedded in $\mathrm{D}$

IF part of the meaning $m$ of $\mathrm{B}$ is embedded in $\mathrm{C}$

IF part of the meaning $m$ of $A$ is embedded in B

THEN A implies $\mathrm{E}$ in terms of meaning:

IF [the dynamics of a learnig community leads to the engagement of students in learning projects because of how the teacher conceives of his/her role] THEN [the teacher, as a guide could engage them in projects in which they take charge of their own classroom and learning processes in an environment that keeps traditional lectring to the minimum required by the educational situation

Second meaning implication thread (I)

IF part of the meaning $m$ of $\mathrm{H}$ is embedded in $\mathrm{I}$

IF part of the meaning $m$ of $\mathrm{G}$ is embedded in $\mathrm{H}$

IF part of the meaning $m$ of $F$ is embedded in $G$

IF part of the meaning $m$ of $\mathrm{A}$ is embedded in $\mathrm{F}$

THEN A AND F imply I in terms of meaning:

IF [the dynamics of a learning community leads to the engagement of students in learning projects because of how the teacher conceives of his/her role] AND IF [a learning community develops students' intellectual competence as well as moral values] THEN [cognitive, metacognitive and moral competence can be enabled by the caring approach of a teacher acting as a guide]

Third meaning implication thread (III)

IF part of the meaning $m$ of $\mathrm{K}$ is embedded in $\mathrm{L}$

IF part of the meaning $m$ of $\mathrm{J}$ is embedded in $\mathrm{K}$

IF part of the meaning $m$ of $A$ is embedded in $\mathrm{J}$

THEN A implies $\mathrm{L}$ in terms of meaning:

IF [the dynamic of a learning community leads to the engagement of students in learning projects because of how the teacher conceives of his/her role] THEN [a learning community not only promotes social interaction but moral action among the students]

Conclusion

IF part of the meaning $m$ of (II) is embedded in (III)

IF part of the meaning $m$ of (II) is embedded in (III)

THEN (I) implies (III) in terms of meaning:

IF [the dynamics of a learning community leads to the engagement of students in projects promoted by a teacher acting as a guide, able to support them to take charge of their own classroom and learning processes] THEN [interaction in the learning communities engenders cognitive and metacognitive processes as well as moral action among the students] 
process, and the ease of software use, knowledge building was found in the traces of student teachers written online discourse. We believe that this finding is relevant because it shows that networked contexts can support collaborative efforts leading to meaningful discourse progression that could not be developed otherwise. We understand that this is critical as future members of the teaching profession are called to prepare a greater number of school learners with higher-level thinking skills that will be immersed in pedagogical contexts in which technology will be at the core of learning processes.

As professors uncover effective ways of engaging university students in networked technologies, they will be more likely to feel at ease with online discourse and to integrate it in the classrooms that they will manage as future teachers. Our results suggest that online discourse, when applied to higher education contexts, can enable student teachers to critically discuss future challenges of their profession. What is new for university professors is the very fact of the opportunity provided by electronic conferencing systems to engage students in online discourse as a way to augment social interaction for learning and knowledge building purposes. 


\section{NOTES}

1. In the model of "Operatory Logic", Piaget describes how processes of classification, ordination, and inferencing evolve in the search of correspondences with the child's thinking development. In the model of "Meaning Implication", Piaget demonstrates how inclusions could not be understood only from the viewpoint of form but also of content by introducing the idea that " $p$ implies $q$... if one meaning $m$ of $q$ is embedded in the meanings of $p$ and if this meaning $m$ is transitive" (1991, p. 3). This model has nothing to do with the partial understanding that most scholars, mainly in psychology, have from his epistemology.

2. We do not intend to add to the discussion about the supposed inconsistencies among constructivism and socioconstructivism because Vygotsky's criticisms were responded to by Piaget himself (1985), and because these authors discuss the same phenomena from entirely different perspectives (psychological: Vygotsky; epistemological: Piaget).

3. In order to enlighten the reader concerning the ambiguity of the terms "construction” proposed by Piaget, "co-construction” proposed by Grize, and "building”, proposed by Scardamalia and Bereiter, we use the first and the second models to point to contexts that are not online while we use the third term when online exchanges are at stake.

4. In our way of describing online communication processes the terms "build" and "building" imply the networked context of electronic conferencing.

5. Some of these functions were borrowed from those identified by the informal logician Toulmin (1958).

6. Grize and Piérault-Le Boniec (1991) explain that ill-defined problem solving writing processes normally deal with different contents at once. Therefore, for methodological purposes, they suggest that the main themes be identified, and that the researcher arbitrarily chooses one of them to follow the process of meaning co-construction.

7. This pedagogical innovation was introduced in Canada by a leading teacher educator and researcher responsible for "Theme 7 - Educating the Educators” of the Telelearning - Network of Centres of Excellence (19962002). 
8. Following broadly recognized methods of logical analysis (Van Eemeren, Grootendorst \& Henkemans, 1996), we restructured the content by applying operations of adding (including words that were subjacent to discourse) or suppression (deleting words that are not fundamental to discourse clarity).

9. Scaffolds are "tags" that can be intentionally inserted in the body of the message by community participants. The scaffolds created in this learning community were: "I submit a problem", "My theory", "Theoretical support", "Putting our knowledge together", "I improve an idea”, "I explore another theory”, and "My evaluation of the situation”.

\section{Acknowledgements}

Funding for this research came from the Social and Human Sciences Research Council of Canada (SHSRC)and the Fonds québécois de recherche sur la société et la culture (FQRSC). We would like to thank Niki Messas and Marcela Quesada, graduate students of the University of Montreal, for the coding of conference transcripts, and Seth J. Batiste, graduate student of the University of Houston, for his thoughtful comments on the transcript and editing work. We would also like to thank the reviewers for their helpful and thoughtful comments.

\section{Correspondence information}

Milton N. Campos

Assistant Professor

Département de communication

Université de Montréal

C.P. 6128, succursale Centre-ville

Montréal, H3C 3J7

Canada

Tel - (514) 343-2066

Fax - (514) 343-2298

E-mail: Milton.Campos@umontreal.ca

Web site: www.interactiva.umontreal.ca 


\section{REFERENCES}

Bereiter, C., \& Scardamalia, M. (1987). The psychology of written composition. Hillsdale, NJ: Lawrence Erlbaum Associates.

Bereiter, C., \& Scardamalia, M. (1996). Rethinking learning. In D. R. Olson, \& N. Torrance, (Eds.), The handbook of education and human development: New models of learning, teaching, and schooling (pp. 485-513). Cambridge, MA: Basil Blackwell.

Breton, P. (1996). L'argumentation dans la communication. Paris: La Découverte.

Breuleux, A. (2001). Imagining the present, interpreting the possible, cultivating the Future: Technology and the renewal of teaching and learning. Education Canada, 41(3), 12-15.

Breuleux, A., \& Laferrière, T. (2000, October). Communities of interpretation within the Telelearning Professional Development Schools. Poster session presented at the CILT 2000: Equity, and K-14 Learning, Center for Innovative Learning Technologies, Washington.

Bruer, J. T. (1994). Schools for thought: A science of learning in the classroom. Cambridge, MA: MIT Press.

Campos, M. N. (1998). Conditional reasoning: A key to assessing computer-based knowledge-building communication processes. Journal of Universal Computer Science, 4(4), 404-428. Retrieved July 11, 2005, from: http://www.jucs.org/jucs_4_4/conditional_reasoning_ a_key

Campos, M. N. (2000). The hypermedia conversation: Reflecting upon, building and communicating ill-defined Arguments. Interactive Multimedia Electronic Journal of Computer-Enhanced Learning, 2(2). Retrieved July 11, 2005, from: http://imej.wfu.edu/articles/2000/2/04/ index.asp

Campos, M. N. (2002). Competition, lies and dissimulation: Lessons from an online learning clash. Interpersonal Computing and Technology Journal, 8 (1). Retrieved July 11, 2005, from: https:// www.aect.org/Intranet/Publications/ipct-j/2002/Campos.asp. 
Campos, M. N. (2003). The progressive construction of communication: Towards a model of cognitive networked communication and knowledge communities. Canadian Journal of Communication, 28(3), 291-322.

Campos, M. N. (2004a). A constructivist method for the analysis of networked cognitive communication, and the assessment of collaborative learning and knowledge-building. Journal of Asynchronous Learning Networks, 8(2), 1-29.

Campos, M. N. (2004b). Healing the health system scars through networked communication. Experimental \& Clinical Cardiology. The Journal of the International Academy of Cardiovascular Sciences, 9(1), 40.

Campos, M.N.(2004c). Health, knowledge, and networked communication. Academic Exchange Quarterly, 8(3), 22-26.

Campos, M. N., \& Laferrière, T. (2002). Internet en éducation: interaction sociale et communication pédagogique en réseau. In J. Lajoie \& É. Guichard, É. (Eds.), Odyssée Internet. Enjeux sociaux. (pp.179-164). Montréal: Presses de l’Université du Québec.

Campos, M. N., Laferrière, T., \& Harasim, L. (2001). The post-secondary networked classroom: Renewal of teaching practices and social interaction. Journal of Asynchronous Learning Networks, 5(2).

Retrieved July 11, 2005, from: http://www.aln.org/alnweb/journal/ jaln-vol5issue2v2.htm

De Kerckhove, D. (1997). Connected intelligence: The arrival of the web society. Toronto: Sommerville House Publishing.

Grize, J.-B. (1991). Logique et langage. Paris: Ophrys.

Grize, J., \& Piéraut-Le Boniec, G. (1991). Logique naturelle et construction des propriétés des objets. L'Année psychologique, 91, 103-120.

Harasim, L. M. (1990). Online education: An environment for collaboration and intellectual amplification. In L.M. Harasim (Ed.), Online education: Perspectives on a new environment (pp. 39-66). New York: Praeger.

Harasim, L. M., Hiltz, S. R., Teles, L, \& Turoff, M. (1995). Learning networks: A field guide to teaching and learning online. Cambridge, MA: MIT Press. 
Haughey, M. (2002, April - May). Canadian research on information and communication technologies: A state of the field. Paper presented at the 2002 Pan-Canadian Education Research Agenda Symposium Information Technology and Learning. Retrieved July 11, 2005, from http://www.cmec.ca/stats/pcera/RSEvents02/MHaughey_OEN.pdf

Hewitt, J. (2001). Beyond threaded discourse. International Journal of Educational Telecommunications, 7(3), 207-221.

Laferrière, T., Campos, M. N., \& Benoit, J. (2004). Apprendre au quotidien dans l'organisation québécoise: Le cas des communautés de pratique virtuelles. Québec: CEFRIO.

Laferrière, T., Murphy, E., \& Campos, M. N. (2005, June). Effective practices in online collaborative learning in campus-based courses. Proceedings of EDMEDIA - World Conference on Educational Multimedia,Hypermedia and Telecommunications, 1878-1885. Norfolk (Virginie), États-Unis, AACE - Association for the Advancement of Computing in Education.

Lamon, M., Scardamalia, M., \& Laferriere, T. (in press). The classroom as a learning community: Learning and knowledge building. In M. Montane (Ed.), International Symposium on Learning Communities. Barcelona: Ministry of Education, Catalunya.

Piaget, J. (1950). Introduction à l'épistémologie génétique. Paris: Presses Universitaires de France.

Piaget, J. (1954). Les Relations entre l'Intelligence et l'Affectivité dans le Développement de l'Enfant. Bulletin de Psychologie, Groupe d'Études de Psychologie de l'Université de Paris, Sorbonne, Paris V, 7, I-III, 143-150, 346-361; 346-361; 699-709.

Piaget, J. (1976a). Ensaio de lógica operatória. São Paulo: Globo/ EDUSP.

Piaget, J. (1976b). Le Possible, l’Impossible et le Nécessaire. Archives de Psychologie, 44, 172, 281-299.

Piaget, J. (1977). Essai sur la Nécessité. Archives de Psychologie, 45, 175, 235-261.

Piaget, J. (1978). Fazer e compreender. São Paulo: Melhoramentos/ EDUSP. 
Piaget, J. (1985). Commentaires sur les remarques critiques de Vygotsky. In J. P. Bronckart et. al.. Vygotsky aujourd'hui (pp.120-137).

Neuchâtel-Paris: Delachaux \& Niestlé.

Piaget, J. (1991). Introduction. In J. Piaget \& R. Garcia, (Eds.), Toward a logic of meanings (pp. 3-8). Hillsdale, NJ: Lawrence Erlbaum Associates.

Scardamalia, M. (2002). Collective responsibility for the advancement of knowledge. In B. Smith (Ed.), Liberal education in a knowledge society (pp.67-98). Chicago: Open Court.

Scardamalia, M., \& Bereiter, C. (1994). Computer support for knowledge building communities. The Journal of the Learning Sciences, 3(3), 265-283.

Scardamalia, M., \& Bereiter, C. (2002). Knowledge building. In Encyclopedia of Education. New York: McMillan Reference, USA.

Toulmin, S. (1958). The uses of argument. Cambridge, MA: Cambridge University Press.

Van Eemeren, F. H., Grootendorst, R., \& Henkemans, F. S. (1996). Fundamentals of argumentation theory. A handbook of historical backgrounds and contemporary developments. Mahwah, NJ: Lawrence Erlbaum Associate, Publishers.

Vygotsky, L. S. (1979). The collected works of L.S. Vygotsky. Problems of general psychology. New York: Plenum Press. 